\title{
頝動脈・頭蓋内主幹動脈狭窄症に対する抗血栓療法
}

\author{
片岡 大治 \\ 国立循環器病研究センター脳神経外科
}

\section{Antithrombotic Therapy for Carotid and Intracranial Artery Stenosis}

\author{
Hiroharu Kataoka, M.D., Ph.D. \\ Department of Neurosurgery, National Cerebral and Cardiovascular Center
}

Recently, the incidence of atherothrombotic cerebral infarction due to cervical internal carotid artery stenosis and intracranial artery stenosis has been increasing as a consequence of changing dietary habits in Japan to more Western style. Antiplatelet therapy is used for the management of atherothrombotic infarction together with the control of risk factors such as hypertension, dyslipidemia and so on. Aspirin, clopidogrel and cilostazol are antiplatelet drugs that are available in Japan and should be used as the situation demands and on the basis of each drug's properties. Although dual antiplatelet therapy (DAPT) is administered for recurrent cases that persist despite single antiplatelet therapy, prolonged DAPT should be avoided because it increases the risk of intracranial hemorrhage. Also, in the acute stage of stroke, Argatroban and Heparin are used in addition to DAPT. In the case of progressing stroke in spite of maximum antithrombotic therapy, surgical revascularization should be considered in a timely manner.

(Received April 12, 2016 ; accepted May 2, 2016)

Key words : antithrombotic therapy, atherothrombotic infarction, dual antiplatelet therapy, revascularization

Jpn J Neurosurg（Tokyo）25: 804-812, 2016

\section{はじめに}

頝部頚動脈や頭蓋内動脈の粥状動脈硬化に伴うアテ ローム血栓性脳梗塞は, 食生活の欧米化などにより近年 増加傾向にあり, 最近の脳卒中データバンクによれば全 脳梗塞の $31 \%$ を占め, $29 \%$ のクナ梗塞を上回ってい る ${ }^{9)}$ ．アテローム血栓性脳梗塞は, 浅側頭動脈-中大脳動 脈バイパス術（STA-MCA bypass）・頝動脈内膜剶離術 （carotid endarterectomy：CEA）などの外科的血行再建の 適応となる場合もあるが，多くの場合は抗血小板療法と 動脈硬化リスク因子のコントロールによる内科治療が第 1 選択となる。抗血小板剂は現在アスピリン, クロピド
グレル, シロスタゾールの3剤が主に使用されているが, 新規抗血小板剂の開発や治験が進行中であり，今後ます ますそれぞれの特性や病態に基づく使い分けが必要に なってくる（Table 1)。また，抗血小板剤は出血のリス クを高めるため，漫然とした長期投与，特に 2 剂併用の dual antiplatelet therapy（DAPT）は避けなければならな い．発症急性期においては，DAPT に加えてアルガトロ バンやへパリンなども使用して最大限の抗血栓療法を行 うが，それらの治療に抵抗性で進行する脳梗塞に対して は，時期を逃さずに外科的血行再建を考慮しなければな らない. 本稿では，アテローム血栓性脳梗塞の急性期か ら慢性期に至るさまざまな場面での抗血小板療法の「判

連絡先：片岡大治， $=565-8565$ 吹田市藤白台 5-7-1 国立循環器病研究センター脳神経外科

Address reprint requests to : Hiroharu Kataoka, M.D., Ph.D., Department of Neurosurgery, National Cerebral and Cardiovascular Center, 5-7-1 Fujishirodai, Suita-shi, Osaka 565-8565, Japan 
Table 1 Comparison of antiplatelet agents

\begin{tabular}{l|l|l|l}
\hline & \multicolumn{1}{|c|}{ Aspirin } & \multicolumn{1}{c}{ Clopidogrel } & \multicolumn{1}{c}{ Cilostazol } \\
\hline Class & Non-steroidal antiinflam- & Second generation thi- \\
enopyridine & Phosphodiesterase-3 inhibitor \\
mesing & Once daily & Once daily & Twice daily \\
Reversibility of action & No & No & Yes \\
Peak effect & $1-3$ hours & Yes & $3-4$ hours \\
Variability with CYP2C19 genotype & No & No & Headter load) \\
Side effects & Gastrointestinal bleeding & Liver dysfunction & Heachycardia \\
When to stop before surgery & Intracranial bleeding & Hematocytopenia & Congestive heart failure \\
\hline
\end{tabular}

断」と「行動」について，最新のエビデンスと知見に基 づいて概説する.

\section{脳梗塞二次予防としての抗血小板療法}

抗血小板療法は，古くから脳梗塞再発予防効果が証明 されてきた治療法であり，アテローム血栓性脳梗塞の二 次予防では gold standard である。特に, 症候性の頭蓋内 主幹動脈狭窄においては，抗凝固薬であるワーファリン はアスピリンと同等の脳梗塞予防効果しか示さないにも かかわらず，頭蓋内出血などの有害事象が有意に高かっ たため ${ }^{4)}$, 最新の脳卒中治療ガイドライン 2015 でも, 非 心原性脳梗塞の再発予防には抗血小板薬がグレードAで 推奨されている14).

\section{1 アスピリン}

アスピリンは, 血小板のシクロオキシゲナーゼ-1 (COX-1）を阻害することにより，トロンボキサン A2 （TXA2）の生成を抑制し，血小板の二次凝集を抑制する (Fig. 1)。アスピリンは脳梗塞二次予防効果において豊 富なエビデンスを有する抗血小板剤であり，抗血栓療法 に関するエビデンスを総括的に解析した国際共同研究の Antithrombotic Trialists' Collaboration（ATT）において, 虚血性脳卒中再発のリスクを $22 \%$ 低減できることが示 された ${ }^{1)}$ 。アスピリンを使用する際に念頭に置くべきこ とは出血性合併症であり, アスピリンは出血性脳卒中の リスクを 1.67 倍増加させることが同じく ATTで示され， わが国のアスピリン服用者の $35.7 \%$ に胃・十二指腸潰瘍 もしくはびらんが発生することも報告されている20).ア スピリン投与の際は，消化性潰瘍の予防のためプロトン ポンプ阻害薬の併用を行うほか, 消化性潰瘍既往例では 他の抗血小板剤を考慮する。

\section{2 クロピドグレル}

クロピドグレルはチエノピリジン系の抗血小板剤の 1 つであり，血小板膜上のアデノシン二リン酸 $(\mathrm{ADP})$ 受 容体である P2Y12 を阻害して, 細胞内の環状アデノシン 一リン酸（cAMP）の濃度を上昇させることにより血小 板凝集を抑制する（Fig. 1)。クロピドグレルはプロド ラッグであり，活性化には CYP 酵素（主に CYP2C19）が 必要である。千エノピリジン系の抗血小板剤には，チク ロピジンもあるが，クロピドグレルはその重大な副作用 である顆粒球減少と肝障害の頻度がチクロピジンより低 いため，安全性においてより優れている。 クロピドグレ ルは，アスピリンとの比較研究である Clopidogrel versus Aspirin in Patients at Risk of Ischaemic Events (CAPRIE) 試験で，アスピリンに対する非劣性が証明されている. CAPRIE 試験は，脳梗塞（発症後 1 週間以上， 6 力月以 内)，心筋梗塞，動脈硬化性末梢血管疾患を有する 19,185 例を対象としたランダム化比較試験（RCT）であり，ク ロピドグレル群のアスピリン群に対する脳梗塞，心筋梗 塞，血管死の年間発症の相対リスク低下率は 8.7\%（95\% $\mathrm{CI}=0.3 \sim 16.5 \%)(\mathrm{p}=0.043)$ と有意であった ${ }^{5}$. ただし， 脳梗塞既往例のみの解析では相対リスク低下率は $7.3 \%$ $(\mathrm{p}=0.26)$ に留まり有意差を示さなかつた。安全性にお いては，頭蓋内出血はアスピリン群 $0.49 \%$ ，クロピドグ レル群 $0.35 \%$ と有意差を認めなかつたが，消化管出血は アスピリン群 $2.66 \%$ に対してクロピドグレル群 $1.99 \%$ と 有意に副作用発現率の低下がみられた。また，糖尿病や 脂質異常症などを合併した動脈硬化ハイリスク患者で は，アスピリンよりも脳梗塞二次予防効果が高いことが 知られており ${ }^{7)}$ ，そのような症例では第 1 選択となる。 クロピドグレルを使用する際の注意点は，プロドラッグ であるため作用発現までに時間がかかることと， CYP2C19で代謝を受けてから活性体になるため，その遺 伝子多型によってクロピドグレルの作用発現に個体差が 生じる点である。CYP2C19 遺伝子多型を extensive 


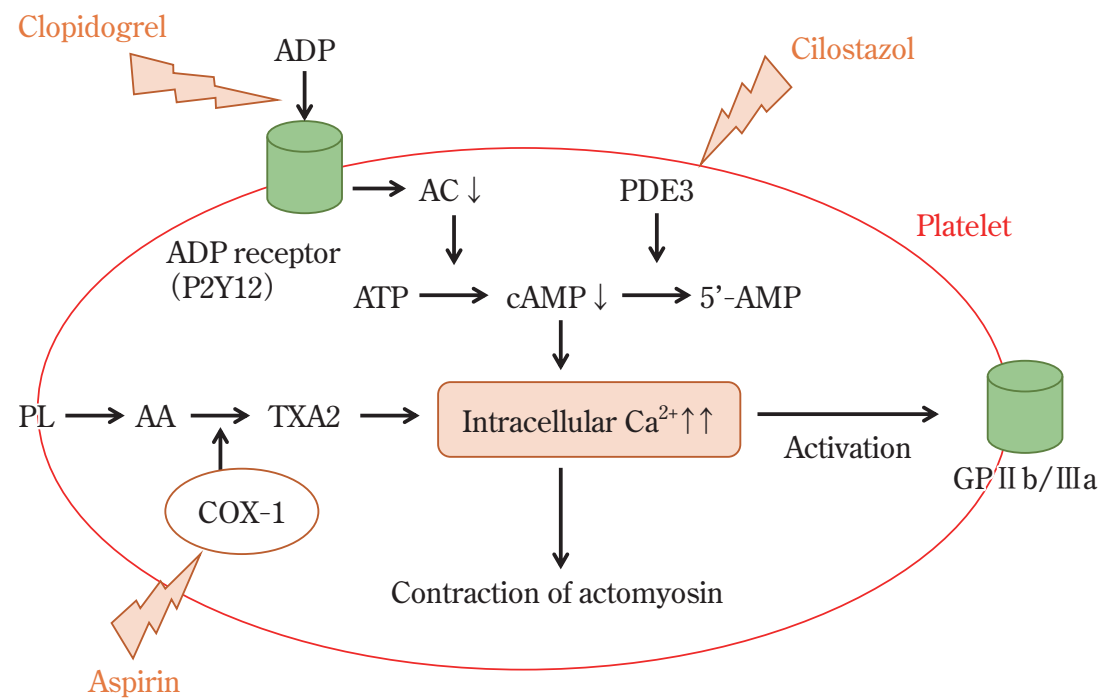

Fig. 1 Action mechanisms of antiplatelet agents

ADP : adenosine diphosphate, AC : adenylate cyclase, ATP : adenosine triphosphate, cAMP : cyclic adenosine monophosphate, PDE3: phosphodiesterase3, PL : phospholipid, AA : arachidonic acid, TXA2 : thromboxane A2, $\mathrm{COX}^{-1}$ : cyclooxygenase -1 , GP II b/IIIa : glycoprotein II b/IIIa

metabolizer 群, intermediate metabolizer 群, poor metabolizer 群に分けて検討を行うと, poor metabolizer 群では 他の群に比べ血小板機能抑制効果が低いことが報告され ており ${ }^{18)}$, poor metabolizer 群は白人では約 $2 \%$ 存在する にすぎないが,アジア人では約 15〜20\%に認められるた め2223)，クロピドグレル抵抗性はアジア人に多い。した がって，血管内治療の周術期など抗血小板剂を確実に効 かせておきたい場面では，透過光測定法（LTA）や VerifyNow を用いた血小板凝集能のモニタリングが必要とな る.

\section{3 シロスタゾール}

シロスタゾールはホスホジエステラーゼ 3 (PDE3) を 阻害することにより, 血小板内の cAMP の濃度を上昇さ せ，血小板の凝集を抑制する（Fig. 1)。その特徴は血管 拡張作用を併せ持つことと, 本邦をはじめとするアジア 人でのエビデンスが豊富な点である。 シロスタゾール (200 mg/日, 2 分服) をプラセボ群と比較した Cilostazol Stroke Prevention Study（CSPS）で, 41.7\%の脳卒中の再 発低減効果を示した ${ }^{6)}$. また, アスピリンとの比較を 行った Cilostazol versus Aspirin for Secondary Ischaemic Stroke Prevention (CASISP) 試験と CSPS2 のメ夕解析で は，アスピリンと同等の脳梗塞再発予防効果を持ち, か つ安全性はアスピリンょり高いことが示された。シロス タゾール群のアスピリン群に対する全脳卒中の相対リス
ク低下率は $13 \% （ 95 \% \mathrm{CI}=0.52 \sim 0.86, \mathrm{p}<0.01 ）$ と有意 で, 特に出血性脳卒中の相対リスク低下率は 74\%（95\% $\mathrm{CI}=0.13-0.55, \mathrm{p}<0.01$ ） と顕著であった〔虚血性脳卒中 については，相対リスク低下率 $20 \% （ 95 \% \mathrm{CI}=0.61$ $1.07, \mathrm{p}=0.13 ）$ と 2 群間で有意差なし $]^{8)}$. シロスタゾー ルの臨床上の問題点は，動悸・頭痛・頻脈といった副作 用発現率が高いことであり，時間的に余裕があるときは 半量から投与を開始するとよい.

\section{4 抗血小板剤 2 剤併用 (DAPT)}

脳梗塞，心筋梗塞をはじめとする血栓塞栓症に対する DAPT のリスク/ベネフィットについてはさまざまな立 場から論じられており，知識を整理しておく必要があ る。アテローム血栓性脳梗塞患者における DAPT も後述 する急性期と慢性期では考え方が異なる。1 年以上の DAPT と抗血小板剂単剂を比較した 7つの RCT のメ夕解 析によると, 脳卒中の再発は 2 群間で差がなく（DAPT 群 vs. アスピリン群： $\mathrm{RR}=0.89 ， 95 \% \mathrm{CI}=0.78 \sim 1.01$; DAPT 群vs. クロピドグレル群：RR=1.01，95\% CI= 0.93〜1.08), 脳出血の発生は DAPT 群とアスピリン群で は有意差が生じなかったが $(\mathrm{RR}=0.99,95 \% \mathrm{CI}=0.70$ 1.42), DAPT 群とクロピドグレル群では有意に DAPT 群 に高いという結果であった（RR=1.48，95\% CI=1.17〜 $1.82)^{11)}$ 。すなおち 1 年以上の DAPT は脳梗塞再発予防効 果という点で単剂を上回る効果が認められず，脳出血の 
0.4

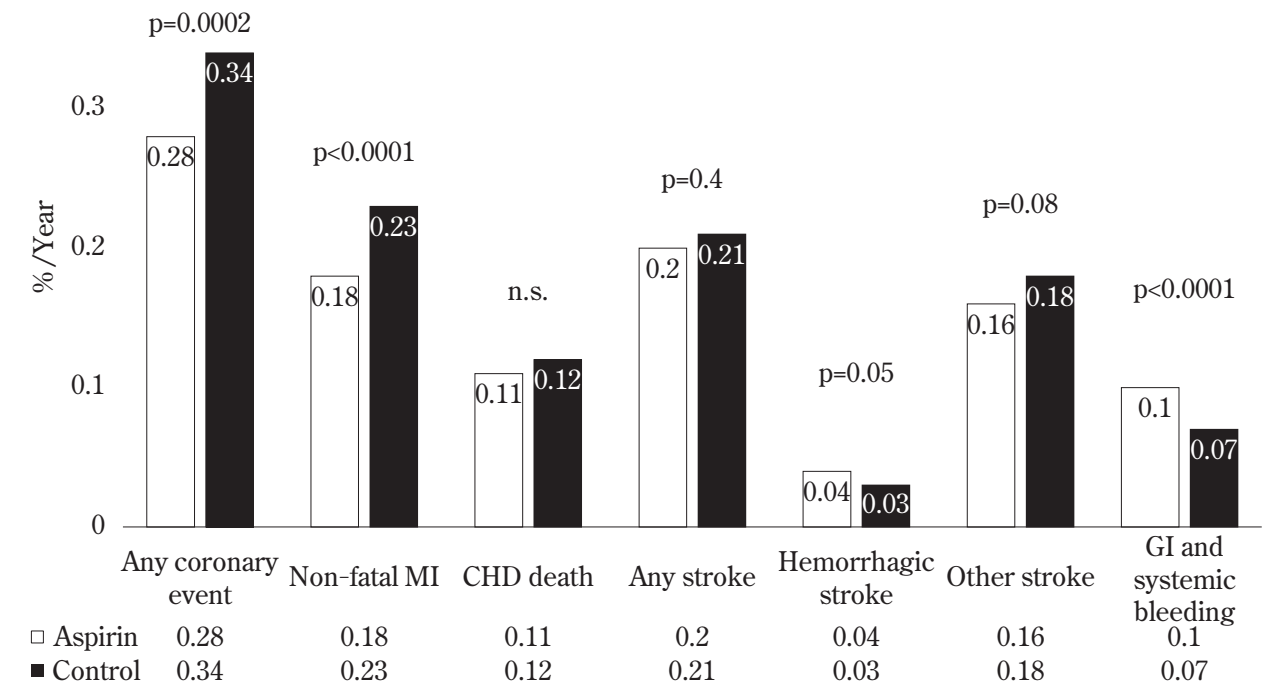

Fig. 2 Primary prevention effect of aspirin for cardiovascular diseases in ATT

Aspirin has no primary prevention effect for stroke although it decreased any coronary event risk by $18 \%$.

リスクを高めるだけであるので, 脳卒中治療ガイドライ ン 2015 でもグレード D で行わないことが勧められてい る ${ }^{14)}$. 一方, 循環器領域, 特に薬剂溶出ステント (DES) 留置後や心筋梗塞既往例では, 1 年以上の DAPT による ベネフィットがリスクを上回るという報告もある ${ }^{12) 19) . ~}$ アテローム血栓性脳梗塞は冠動脈病変を合併する頻度が 高く, DAPT の継続の是非は個々の症例ごとに他科領域 の主治医と相談して決めていかなければならない.

\section{脳梗塞一次予防としての抗血小板療法}

先述の ATTでは, 疾病の既往のない患者を対象とした 一次予防効果の有無を検証した 6 つの RCT に登録され た 95,000 例のメ夕解析も行っている. その結果, アスピ リンは主要冠イベントを $18 \%$ 低減させるが, 全脳卒中は 減少させていなかった ${ }^{1)}$ 。これは, 虚血性脳卒中を減少 させる効果を, 出血性脳卒中を増加させることで相殺し てしまうためであった（Fig. 2)。無症候性頝部頝動脈狭 窄や頭蓋内主幹動脈狭窄に対して, 抗血小板剤投与が脳 卒中発症を予防するというエビデンスも存在しない.し たがって, 脳卒中治療ガイドライン 2015 で,「無症候 性脳主幹動脈狭窄ならびに閉塞病変に対しては，他の心 血管疾患の併存や出血性合併症のリスクなどを総合的に 評価した上で, 必要に応じて抗血小板療法を行うことを 考慮して良い（グレード C1）」という表現になってい $3^{14)}$ 。無症候性頝動脈狭窄においても同様であり, 無症
候性軽度頝動脈狭窄に漫然と抗血小板剂を投与すること は慎まなければならない。

\section{脳梗塞急性期における抗血栓療法}

発症 48 時間以内の脳梗塞急性期の抗血栓療法として 国際的に広く認められた治療は，長らくアスピリンの経 口投与のみであった. International Stroke Trial（IST）と Chinese Acute Stroke Trial（CAIST）のメ夕解析では，ア スピリン $160 \sim 300 \mathrm{mg}$ /日の投与により, 脳梗塞再発が減 少し $(1.6 \% \mathrm{vs} 2.3 \%)$, 脳卒中の発症または死亡が有意に 減少することが示された $(8.2 \% \text { vs. } 9.1 \%)^{3)}$.これらの工 ビデンスに基づき，アスピリン 160〜 $300 \mathrm{mg} /$ 日の投与は 脳卒中治療ガイドライン 2015 でもグレード A で推奨さ れている ${ }^{14)}$ 。実際の臨床現場では, 急性期脳梗塞に対し て，オザグレルナトリウム，アルガトロバン，ヘパリン の点滴が併用されることが少なくない.オザグレルナト リウムは，トロンボキサン A2 合成阻害薬であり，長期 的な機能予後や死亡率の改善に関しては明らかではない が，神経症状の改善効果が示されており ${ }^{24)}$ ，脳卒中治療 ガイドライン 2015 ではグレードBで推奨されている ${ }^{14)}$. アルガトロバンは，わが国で開発された選択的な合成抗 トロンビン薬で抗凝固薬に分類され, 発症 48 時間以内 の脳血栓症において神経症状の改善をもたらし, 出血性 合併症が少ないことが報告されており ${ }^{10)}$, やはり脳卒中 治療ガイドライン 2015 の推奨はグレード B である ${ }^{14)}$. 


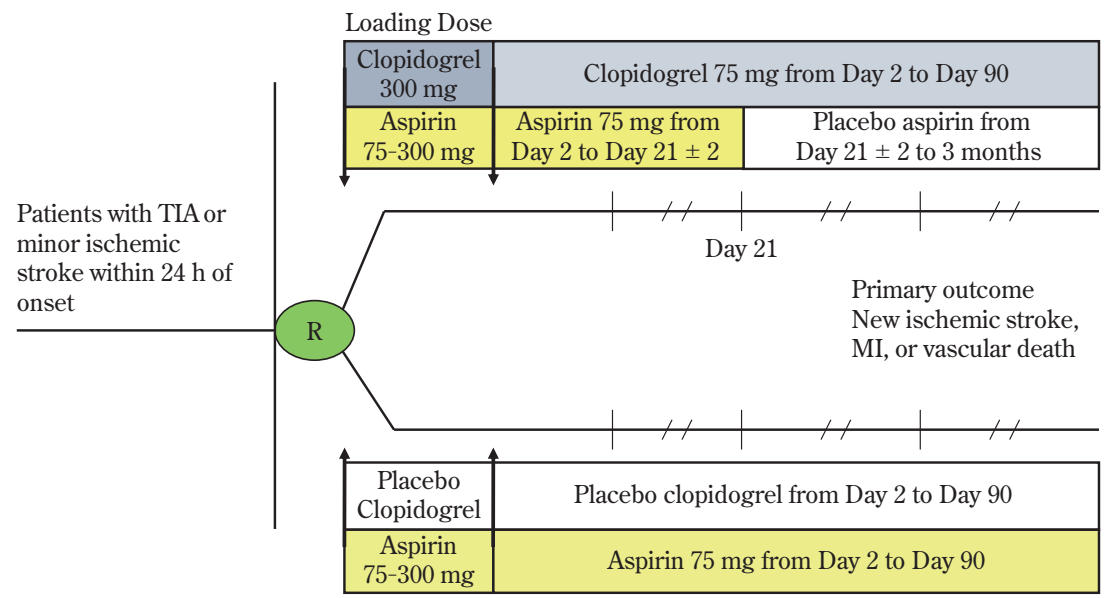

Fig. 3 The CHANCE trial study protocol

The Clopidogrel in High-Risk Patients with Acute Nondisabling Cerebrovascular Events (CHANCE) trial tested the effect of early dual antiplatelet treatment (DAPT) for the prevention of secondary stroke within the first 90 days following a qualifying transient ischemic attack (TIA) or minor stroke in 5,170 Chinese patients. Note that DAPT continued for only 3 weeks from the onset in the DAPT group.

ヘパリンに関しては, メ夕解析の結果, 急性期脳梗塞に おいて脳梗塞再発を抑制するが（HR 0.76；95\%CI 0.65〜 0.88), 症候性頭蓋内出血を増加させるため（HR 2.99； $95 \%$ CI 2.24 3.99), 全死亡（HR 1.05；95\%CI 0.98〜 1.22）や死亡または要介助（HR $0.99 ; 95 \%$ CI $0.93 \sim 1.04 ）$ を減少させない ${ }^{15)}$ 。実臨床では用いられることが依然多 いため, 脳卒中治療ガイドライン 2015 の推奨はグレー ド C1 となっているが14)，使用する際には出血性合併症 とのリスク/ベネフィットに留意する必要がある。

これらに加えて, 最近急性期脳梗塞に対するアスピリ ンとクロピドグレル併用による DAPT の有効性のエビデ ンスが確立しつつある。その端緒は 2013 年に発表され た Clopidogrel in High-Risk Patients with Acute Nondisabling Cerebrovascular Events（CHANCE）試験である. これは, 発症から 24 時間以内に治療可能な一過性脳虚 血発作（TIA）または軽症脳卒中患者 5,170 例をクロピド グレル+アスピリンの DAPT 群とプラセボ+アスピリン のアスピリン群に分けて, 90 日間の脳卒中再発予防につ いて解析した研究で，全脳卒中は DAPT 群 $8.2 \%$ に対し てアスピリン群 $11.7 \%$ で有意に抑制されており（HR $0.68 ; 95 \% \mathrm{CI} 0.57 \sim 0.81, \mathrm{p}<0.001)$, すべての出血性合併 症は DAPT 群 $2.3 \%$ に対して, アスピリン群 $1.6 \%$ と有意 差を生じなかった（HR 1.41；0.95〜2.10, $\mathrm{p}=0.09)^{21)}$. CHANCE 試験の特徴は DAPT の継続期間が 3 週間のみ である点であり（Fig. 3)，脳卒中治療ガイドライン 2015 でも発症亜急性期までの治療としてグレードBで推奨さ
れている ${ }^{14)}$. 現在, TIA と軽症虚血性脳卒中患者の急性 期における虚血性血管イベントの予防において，アスピ リンとクロピドグレル併用の DAPT の意義を検討する Platelet-Oriented Inhibition in New TIA and minor ischemic stroke（POINT）試験をはじめとするいくつかの RCT が進行中であり，その結果が注目される。

\section{脳梗塞急性期における抗血栓療法の限界 一外科的血行再建術の「判断」と「行動」一}

TIA や軽症脳梗塞の症例では，発症早期の神経症状の 悪化や脳梗塞再発が多く, 頚動脈狭窄や頭蓋内主幹脳動 脈狭窄を伴う症例では，さらに再発の危険性が高いこと が知られている ${ }^{13)}$ 。症候性の頝部䅡動脈狭窄や頭蓋内主 幹動脈狭窄・閉塞例で，急性期の $\mathrm{rt}-\mathrm{PA}$ 静注療法や血管 内治療による血栓回収療法の適応にならない場合は，ま ず上述の抗血栓療法を含めた内科治療を開始する。 Shahidi ら ${ }^{17)}$ は，DAPT にスタチンを加えた積極的内科治療 により急性期の脳梗塞再発が有意に減少することを報告 している。もつとも彼らの報告でも，4,905 例中 115 例に 急性期 CEAが施行されており, 最大限の内科治療を行っ ても脳梗塞の再発や神経症状の悪化をきたす症例も存在 し，そのような場合には時期を逃さずに外科的血行再建 を行う必要がある。その代表例を以下に示す。

症 例：73 歳男性。右上肢巧緻運動障害で当院に救急 搬送され，入院時 MRI 拡散強調画像で，左前頭葉運動領 

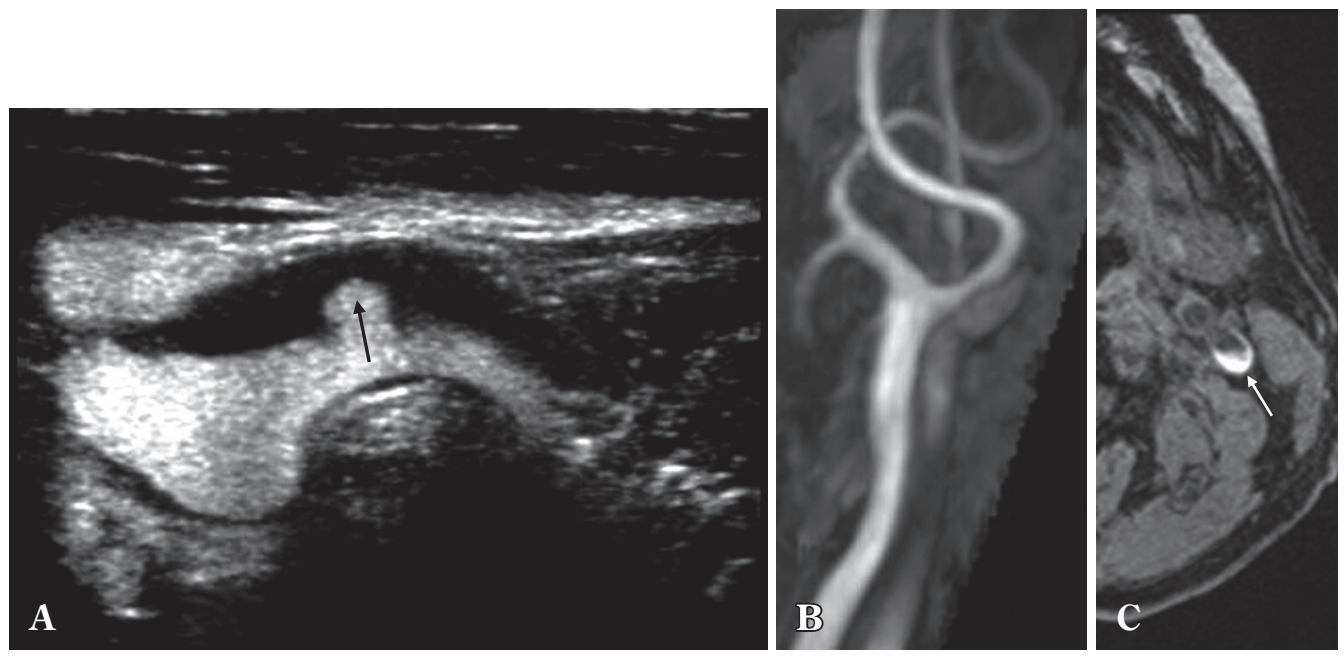

Fig. 4 A case of stroke in evolution despite maximum medical treatments

A : Contrast-enhanced harmonic ultrasonography with Sonazoid in the left carotid artery showed a low-echoic plaque with ulceration (arrow).

B : Time of flight magnetic resonance angiography（TOF-MRA） showed moderate carotid artery stenosis with a hyperintensity plaque.

$\mathrm{C}:$ The plaque was visualized hyperintensity in magnetization prepared rapid gradient echo (MPRAGE) imaging (arrow).

を中心に散在性の急性期脳梗塞を認めた。頝動脈エコー で，潰瘍を伴う低輝度エコーのプラークを左内頝動脈に 認め（Fig. 4A），同部位からの A to A embolism と考元， 入院後ただちに内科治療を開始した。頝部 MRI/MRAで は，左総頝動脈から内頝動脈にかけてプラークを認め (Fig. 4B)，プラーク性状は MPRAGE 高信号の不安定プ ラークの所見であった(Fig. 4C). 発症前からクロピドグ レル $75 \mathrm{mg}$ /日の内服を行っていたため, アスピリン 200 $\mathrm{mg} /$ 日を加えて DAPT とし, アルガトロバン点滴を 48 時 間行った後にへパリンを 15,000 単位/日で持続投与した (Fig. 5)。 それでも右上肢脱力の増悪と画像上の梗塞巣 の増加がみられたため, 入院 5 日目からシロスタゾール を加えたが，さらに症状の悪化と脳梗塞が拡大したた め, 入院 8 日目に CEA を施行した. CEA 後, 新たな脳 梗塞の拡大はみられず, 症状も徐々に改善して軽度の右 上肢巧緻運動障害のみとなり, modified Rankin Scale （mRS）1で退院となった。

このような急性期の外科的血行再建術の有用性を示す RCT はなく, 症例集積研究に留まるため, 高いエビデン スレベルのデータはない. 本邦の脳卒中治療ガイドライ ン 2015 においても, CEA, 頚動脈ステント留置術 (CAS)， EC-ICバイパスともに，「(勧告を行うだけの十 分な資料がなく, ) 考慮してもよい（グレード C1）」とい う表現に留まっている ${ }^{14)}$. 一方, 米国 14 学会のガイドラ インでは, 「TIA, 脳梗塞で発症した場合, 早期治療が禁
忌でない場合には, 発症から 2 週間以内の早期血行再建 術を施行することは合理的である（Class II a, Level of Evidence B)」という推奨がなされている。これは, 主に Rothwell ら ${ }^{16)}$ による European Carotid Surgery Trial (ECST) と North American Symptomatic Carotid Endarterectomy Trial (NASCET) の pooled data の解析に基づくも のであり, 発症急性期のCEAを推奨する根拠として引用 されることが多い.しかしながら，ECST やNASCETで は, mRS 3 以上の重症脳梗塞, stroke in evolution, crescendo TIA などは除外されており, 神経症候が安定して いる症例のみが対象になっている点に注意しなければな

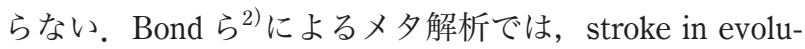
tion が HR 3.2 (95\%CI 1.9-5.6)， urgent case が HR 11.6 (95\%CI 5.1〜>10), crescendo TIA が HR 7.5 (3.7〜>10) とそれぞれCEAのリスク因子となっており，急性期神経 症状が不安定な状態での CEA は八イリスクハイリター ンの治療であることがわかる。これは，プラーク自体の 不安定性や虚血再灌流に伴う過灌流のリスクに加えて, 冠動脈病変などの全身性合併症のリスクの評価が不十分 なまま手術に望まざるを得ないことに起因する。した がって，急性期の症候性䅡動脈狭窄に対しては，DAPT を含む内科治療を最大限に行い, 症候を安定させてから 亜急性期もしくは慢性期に CEA・CAS を行うことを第 1 に考えるべきであろう。近年，無症候性頚動脈狭窄に対 する内科治療の向上が注目されているが，急性期の内科 
Day 1

Day 5

Day 8

\begin{tabular}{|c|c|c|c|}
\hline \multirow{3}{*}{ Clopidogrel } & & & \\
\hline & Aspirin & & \\
\hline & Argatroban & & \\
\hline & & Heparin & \\
\hline & & & Cilostazol \\
\hline
\end{tabular}

Motor paresis
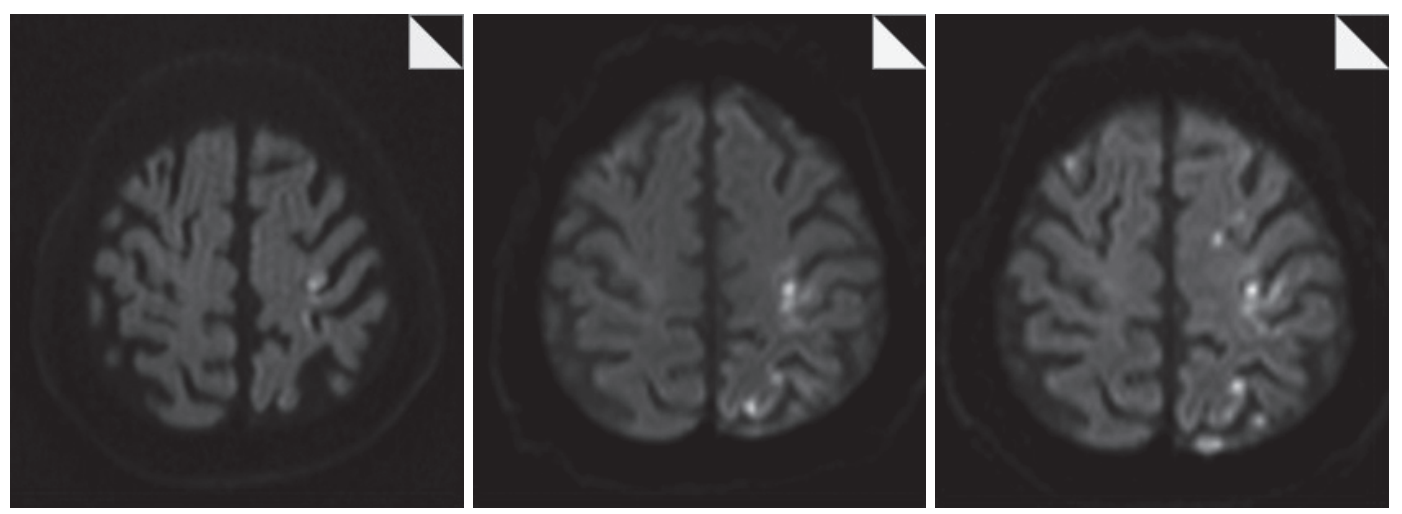

Fig. 5 The clinical course of the case to carotid endarterectomy (CEA)

Despite medical treatments including DAPT and argatroban/heparin, hyperintensity areas on diffusion weighted image (DWI) continued to enlarge and the patient's symptom worsened. CEA was performed after 8 days from admission.

治療も進歩しており，ECST やNASCET の時代と比較す ると治療成績は向上している可能性がある。まず最大限 に内科治療を行って, それでも症状の悪化や脳梗塞の進 展がみられる症例に対してのみに, 時期を逃さずに CEA を行うというのが正しい考方方ではないかと思われる。 外科的血行再建術の方法としては, CAS も治療選択に挙 がるが，一般的に急性期症例は著しい不安定プラークで あることが多く, CEAハイリスクの症例でなければCEA を優先して考慮すべきである。頭蓋内主幹動脈の狭窄や 閉塞の場合も同様で，まず発症急性期は最大限の内科治 療を行うが，それでも症状の悪化や脳梗塞に拡大がみら れる場合には，STA-MCAバイパス術を考慮する。ただ し, 急性期バイパスは, 慢性期のそれと比較すると, 過 灌流症候群・出血性合併症や術後脳梗塞のリスクが高い という点で, CEAの場合と同様である.

\section{おわりに}

抗血小板療法は脳梗塞, とりわけアテローム血栓性脳 梗塞の治療や予防において中核となる治療法である。さ まざまなエビデンスによってコンセンサスが得られてい る部分も多く，それらはガイドライン上で推奨されてい る. ガイドラインはエビデンスに基づいて策定されるた め，ガイドライン上の推奨がどのようなエビデンスに基 づいているのかというところまで熟知して, 実際の臨床 現場では判断を行わなければならない。一方, エビデン スが不十分な治療は，ガイドラインには収載されず，収 載されていてもその推奨レベルは低いものに留まる。 そ のような部分での「判断」と「行動」は個々の症例の病 態とその治療のリスク/ベネフィットを勘案して決定し ていかなければならない. 


\section{COI 開示}

著者は日本脳神経外科学会への COI 自己申告の登録を完了

しています。

本論文に関して開示すべき COI はありません.

\section{文 献}

1) Antithrombotic Trialists' (ATT) collaboration, Baigent $C$, Blackwell L, Collins R, Emberson J, Godwin J, Peto R, Buring J, Hennekens C, Kearney P, Meade T, Patrono C, Roncaglioni $\mathrm{MC}$, Zanchetti A : Aspirin in the primary and secondary prevention of vascular disease : collaborative metaanalysis of individual participant data from randomised trials. Lancet $373:$ 1849-1860, 2009.

2) Bond R, Rerkasem K, Rothwell PM : Systematic review of the risks of carotid endarterectomy in relation to the clinical indication for and timing of surgery. Stroke $34: 2290-$ 2301, 2003.

3) Chen ZM, Sandercock P, Pan HC, Counsell C, Collins R, Liu LS, Xie JX, Warlow C, Peto R: Indications for early aspirin use in acute ischemic stroke: A combined analysis of 40000 randomized patients from the chinese acute stroke trial and the international stroke trial. On behalf of the CAST and IST collaborative groups. Stroke $\quad 31: 1240-1249,2000$.

4) Chimowitz MI, Lynn MJ, Howlett-Smith H, Stern BJ, Hertzberg VS, Frankel MR, Levine SR, Chaturvedi S, Kasner SE, Benesch CG, Sila CA, Jovin TG, Romano JG, Warfarin-Aspirin Symptomatic Intracranial Disease Trial Investigators: Comparison of warfarin and aspirin for symptomatic intracranial arterial stenosis. N Engl J Med 352: 1305-1316, 2005.

5) CAPRIE Steering Committee: A randomised, blinded, trial of clopidogrel versus aspirin in patients at risk of ischaemic events (CAPRIE). CAPRIE Steering Committee. Lancet 348: 1329-1339, 1996.

6) Gotoh F, Tohgi H, Hirai S, Terashi A, Fukuuchi Y, Otomo E, Shinohara Y, Itoh E, Matsuda T, Sawada T, Yamaguchi T, Nishimaru K, Ohashi Y : Cilostazol stroke prevention study: A placebo-controlled double-blind trial for secondary prevention of cerebral infarction. J Stroke Cerebrovasc Dis 9:147-157, 2000.

7) Hirsh J, Bhatt DL : Comparative benefits of clopidogrel and aspirin in high-risk patient populations : lessons from the CAPRIE and CURE studies. Arch Intern Med 164:2106$2110,2004$.

8) Kamal AK, Naqvi I, Husain MR, Khealani BA : Cilostazol versus aspirin for secondary prevention of vascular events after stroke of arterial origin. Cochrane Database Syst Rev : CD008076, 2011.

9）小林祥泰編: 脳卒中データバンク 2015. 東京, 中山書店, 2015.

10) Kobayashi S, Tazaki $Y$ : Effect of the thrombin inhibitor argatroban in acute cerebral thrombosis. Semin Thromb Hemost 23 : 531-534, 1997.

11) Lee M, Saver JL, Hong KS, Rao NM, Wu YL, Ovbiagele B : Risk-benefit profile of long-term dual- versus single-antiplatelet therapy among patients with ischemic stroke: a systematic review and meta-analysis. Ann Intern Med 159: 463-470, 2013.

12) Mauri L, Kereiakes DJ, Yeh RW, Driscoll-Shempp P, Cutlip DE, Steg PG, Normand SL, Braunwald E, Wiviott SD, Cohen DJ, Holmes DR Jr, Krucoff MW, Hermiller J, Dauer- man HL, Simon DI, Kandzari DE, Garratt KN, Lee DP, Pow TK, Ver Lee P, Rinaldi MJ, Massaro JM ; DAPT Study Investigators: Twelve or 30 months of dual antiplatelet therapy after drug-eluting stents. N Engl J Med $\mathbf{3 7 1}$ : 2155-2166, 2014.

13) Merwick A, Albers GW, Amarenco P, Arsava EM, Ay H, Calvet $\mathrm{D}$, Coutts SB, Cucchiara BL, Demchuk AM, Furie KL, Giles MF, Labreuche J, Lavallée PC, Mas JL, Olivot JM, Purroy F, Rothwell PM, Saver JL, Sheehan OC, Stack JP, Walsh C, Kelly PJ : Addition of brain and carotid imaging to the $\mathrm{ABCD}^{2}$ score to identify patients at early risk of stroke after transient ischaemic attack: a multicentre observational study. Lancet Neurol 9: 1060-1069, 2010.

14）日本脳卒中学会, 脳卒中ガイドライン委員会編：脳卒中 治療ガイドライン 2015。東京, 協和企画, 2015.

15) Paciaroni M, Agnelli G, Micheli S, Caso V : Efficacy and safety of anticoagulant treatment in acute cardioembolic stroke : a meta-analysis of randomized controlled trials. Stroke 38: 423-430, 2007.

16) Rothwell PM, Eliasziw M, Gutnikov SA, Warlow CP, Barnett $\mathrm{HJ}$; Carotid Endarterectomy Trialists Collaboration : Endarterectomy for symptomatic carotid stenosis in relation to clinical subgroups and timing of surgery. Lancet $363: 915^{-}$ 924, 2004.

17) Shahidi S, Owen-Falkenberg A, Hjerpsted U, Rai A, Ellemann $\mathrm{K}$ : Urgent best medical therapy may obviate the need for urgent surgery in patients with symptomatic carotid stenosis. Stroke 44:2220-2225, 2013.

18) Sibbing D, Koch W, Gebhard D, Schuster T, Braun S, Stegherr J, Morath T, Schömig A, von Beckerath N, Kastrati A : Cytochrome $2 \mathrm{C} 19 * 17$ allelic variant, platelet aggregation, bleeding events, and stent thrombosis in clopidogreltreated patients with coronary stent placement. Circulation $121: 512-518,2010$.

19) Udell JA, Bonaca MP, Collet JP, Lincoff AM, Kereiakes DJ, Costa F, Lee CW, Mauri L, Valgimigli M, Park SJ, Montalescot G, Sabatine MS, Braunwald E, Bhatt DL : Long-term dual antiplatelet therapy for secondary prevention of cardiovascular events in the subgroup of patients with previous myocardial infarction : a collaborative meta-analysis of randomized trials. Eur Heart J 37 : 390-399, 2016.

20) Uemura N, Sugano K, Hiraishi H, Shimada K, Goto S, Uchiyama S, Okada Y, Origasa H, Ikeda Y; MAGIC Study Group : Risk factor profiles, drug usage, and prevalence of aspirin-associated gastroduodenal injuries among high-risk cardiovascular Japanese patients: the results from the MAGIC study. J Gastroenterol $49:$ 814-824, 2014.

21) Wang Y, Wang Y, Zhao X, Liu L, Wang D, Wang C, Wang C, Li H, Meng X, Cui L, Jia J, Dong Q, Xu A, Zeng J, Li Y, Wang Z, Xia H, Johnston SC ; Investigators CHANCE : Clopidogrel with aspirin in acute minor stroke or transient ischemic attack. N Engl J Med 369: 11-19, 2013.

22) Xie HG, Kim RB, Wood AJ, Stein CM : Molecular basis of ethnic differences in drug disposition and response. Annu Rev Pharmacol Toxicol 41:815-850, 2001.

23) Yamamoto K, Hokimoto S, Chitose T, Morita K, Ono T, Kaikita K, Tsujita K, Abe T, Deguchi M, Miyagawa H, Saruwatari J, Sumida H, Sugiyama S, Nakagawa K, Ogawa H : Impact of CYP2C19 polymorphism on residual platelet reactivity in patients with coronary heart disease during antiplatelet therapy. J Cardiol 57: 194-201, 2011.

24) Zhang J, Yang J, Chang X, Zhang C, Zhou H, Liu M : Ozagrel 
要旨

頚動脈・頭蓋内主幹動脈狭窄症に対する抗血栓療法

片岡 大治

頚動脈狭窄や頭蓋内主幹動脈狭窄などによるアテローム血栓性脳梗塞は, 食生活の欧米化などの影 響で, 近年わが国でも増加しつつある. アテローム血栓性脳梗塞に対する内科治療では, 高血圧・脂 質異常症などのリスク因子のコントロールとともに, 抗血小板療法が選択される. 現在わが国で使用 可能な抗血小板剤は, アスピリン, クロピドグレル, シロスタゾールの 3 種類であり, それぞれの特 性に応じて使い分ける必要がある. また, 抗血小板剤内服下での再発などに対しては, 抗血小板剂 2 剤併用の dual antiplatelet therapy（DAPT）が行われるが, 長期の DAPT は頭蓋内出血のリスクを増 加させるため急性期に留める. 急性期には, DAPT に加えてアルガトロバンやへパリンが使用される が, これらの抗血栓療法を最大限に行っても脳梗塞が進行する場合には, 時期を逃さずに急性期の外 科的血行再建術を考慮する必要がある.

脳外誌 $25 ： 804-812,2016$ 